4. Ampicillin appears to be a most valuable antibiotic for urinary tract infections but courses of the drug should probably be for a minimum of 10 days with adequate laboratory follow-up studies.

I wish to thank my colleagues and Dr. W. M. C. Keane, Medical Superintendent of St. Vincent's Hospital, Melbourne, both for their co-operation and also for permission to present these results. My thanks are due to Miss E. Binns and her staff of the Medical Records Department of this hospital. Mrs. S. Dixson gave me expert technical assistance. The Hospitals and Charities Commission of Victoria provided financial help.

\section{REFERENCES}

Braude, A. I., and Berkowitz, H. (1961): J. Lab. clin. Med., 57, 490.

Brown, D. M., and ACred, P. (1961): Brit. med J., ii, 197.

Brumfitt, W., Percival, A., Carter, M. J. (1962): Lancet, i, 130.
Christie, R. (1963): Personal Communication.

Garrod, L. P., Shooter, R. A., and Curwen, M. P.ב (1954): Brit. med. J., ii, 1003.

HÖFFLER, D., and SCHELER, F. (1963): Disch. med. Weld., $20,1126$.

Kass, E. H. (1955): Amer. J. Med., 18, 764. (1961): Brit. med. J., ii, 198.

LOCKEY, E., EATON, B. R., and COMPSTON, N. (1962): Brit. J. clin. Pract., 16, 13.

Rolinson, G. N., and STEVenS, S. (1961): Brit. med. J., ii, 191.

Ross, E. J. (1964): Prescriber's Journal, 3, 102.

Simmons, N. A., and Williams, J. D. (1962): Lancet, i, 1377 .

Stewart, G. T., Coles, H. M. T., Nixon, H. H., and HoLT, R. J. (1961): Brit. med. J., ii, 200.

StRATFORD, B. C. (1962): Med. J. Aust., 2, 414.

Trafford, J. A. P., Maclaren, D. M., LillicrapC D. A., Barnes, R. D. S., Houston, J. C., and 3 . KNOX, R. (1962): Lancet, i, 987.

TrinCA, J. C. (1962): Med. J. Aust., 2, 428.

Zylka, W., Christener, M., and Moers, H. (1962): Arzneimittel-Forsch., 12, 803.

\title{
AMPICILLIN IN BACTERIURIA AND PYELONEPHRITIS OF PREGNANCY
}

\author{
Priscilla KinCaid-Smith* \\ Senior Associate in Medicine, Department of Medicine, University of Melbourne. \\ Honorary Physician, Queen Victoria Hospital, Melbourne.
}

ASYMPTOMATIC bacteriuria is present in about six per cent of pregnant women and about half these women develop pyelonephritis of pregnancy. Kass' (1960, 1962) findings suggested that pyelonephritis of pregnancy could be virtually eliminated by treatment of bacteriuria, because no pyelonephritis occurred in his non-bacteriuric patients or in those receiving treatment for bacteriuria. He also found that the high incidence of prematurity and perinatal mortality in his bacteriuric patients was reduced by treatment. Because of the important implications of these observations and because other findings had not been entirely in agreement with those of Kass (Kaitz and Hodder 1961, Turck, Goffe and Petersdorf 1962, Turner, 1961) we instituted a double blind controlled trial of anti-bacterial drugs in pregnancy bacteriuria.

Our own findings in a pilot study like those

*In receipt of a Research Fellowship from the National Health and Medical Research Council of Australia. of Kass (1960) suggested that continuouss administration of an anti-bacterial drug waso necessary to control bacteriuria. In selecting a drug for continuous administration during pregnancy, ampicillin seemed a good choice in that it was effective in urinary tract infec tions and being a penicillin was unlikely to have serious toxic effects on mother or fœtus. Sufficient supplies were not available, how:ever, and ampicillin was therefore used onlye. in infections resistant to sulphonamides, sulphamethoxydiazine being used to control the bacteriuria in most patients.

\section{Methods}

Bacterial counts by a spread plate technique $\mathbb{N}$ were done on mid-stream urine specimens collected at the first ante-natal visit in 4,000 women. Six $\mathrm{N}$ per cent of these showed bacteriuria ( $>100,000 \mathrm{\omega}$ organisms $/ \mathrm{ml}$.). Patients with bacteriuria were allo-o cated at random to placebo or treatment and seen< at monthly intervals in a special clinic for clinical, bacteriological and biochemical assessment. In addition to bacterial counts, quantitative leucocyte? counts were performed on urine specimens. 
TABLE I

Symptomatic Urinary Tract Infection (Pyelonephritis)

\begin{tabular}{lccc}
\hline & Total No. & $\begin{array}{c}\text { Symptomatic } \\
\text { Infection }\end{array}$ & Percentage \\
$\begin{array}{l}\text { No bacteruria at first antenatal } \\
\text { visit }\end{array}$ & 4,000 & 48 & 1.2 \\
$\begin{array}{l}\text { PLCEBO GROUP } \\
\text { Bacteriuria at first antenatal }\end{array}$ & 60 & 19 & 31 \\
$\begin{array}{l}\text { visit } \\
\text { TREATMENT GROUP }\end{array}$ & $(47)$ & $(19)$ & $(40)$ \\
Bacteriuria at first antenatal & 64 & $1 *$ & 1.5 \\
visit & $(55)$ & $(1)$ & $(1.8)$ \\
\hline
\end{tabular}

( ) Patients with Bacteriuria on two occasions Persistent Bacteriuria

Ampicillin in a dose of $500 \mathrm{mg}$. thrice daily was used for the treatment of bacteriuria.

For the treatment of pyelonephritis in pregnancy or the post-partum period a two-week course of $500 \mathrm{mg}$. ampicillin four times a day was given. Before treatment was started a urinary bacterial count and leucocyte count was performed and this was repeated three days after the treatment was stopped. Thereafter the urine was examined one week, six weeks, and six months after delivery.

\section{Results}

\section{Treatment of Bacteriuria}

Our results have confirmed that there is a high incidence of pyelonephritis of pregnancy in patients with bacteriuria and that this can be prevented by treatment (Table I). The one patient who developed pyelonephritis while on an anti-bacterial drug was receiving ampicillin, her original bacteriuria had been replaced by a different organism resistant to ampicillin shortly before the symptoms developed.

We have not been able to diminish the high incidence of prematurity, fœtal loss and preeclamptic toxaemia which occurs in bacteriuria by treatment with an appropriate anti-bacterial drug.

Figs. 1 and 2 show the urinary bacterial counts and leucocyte excretion rates in 11 patients who were allocated to ampicillin treatment because their bacteriuria was resistant to sulphonamides. The bacterial count and leucocyte excretion rate usually fell sharply when treatment was started and remained normal for the rest of pregnancy, in about $25 \%$ of patients however the bacteriuria persisted in spite of treatment. Among the 11 cases receiving ampicillin, in three, the bacterial count was still over 100,000 organisms per $\mathrm{ml}$. a month after treatment was started and as might be expected the organism was now resistant to ampicillin. One of these three patients developed the clinical features of pyelonephritis.

Intravenous pyelograms done in the postpartum period showed that $50 \%$ of all bacteriuric patients had radiological renal abnormalities (Table II). Of the 11 patients in whom the bacteriuria was treated with ampicillin, six had an underlying abnormality. Failure to respond to treatment and a persistently high leucocyte excretion rate were particularly liable to occur in patients with an underlying calculus or chronic pyelonephritis (see p. 23).

There was a defaulter rate of $23 \%$ and most of these were due to failure to take tablets continuously. In five of 13 defaulters initially allocated to ampicillin, side effects of the capsules (vomiting in four and rash in one) were directly responsible for the failure to take tablets. A further two patients initially allocated to ampicillin treatment had to be changed to another drug because of vomiting. Thus $24 \%$ of patients allocated to ampicillin had to stop taking it because of side effects. One foetal abnormality was observed in patients who had taken ampicillin during pregnancy. However, this patient had only taken two doses of ampicillin at approximately 20 weeks and there was certainly no causal relationship between this and the grossly malformed foetus which was born four weeks later.

\section{Treatment of Pyelonephritis}

Twenty-four patients with signs and symptoms of acute pyelonephritis of pregnancy were treated with ampicillin. Seven of these patients were subsequently shown to have underlying chronic renal disease. The results of treatment are shown in Table III. Two 


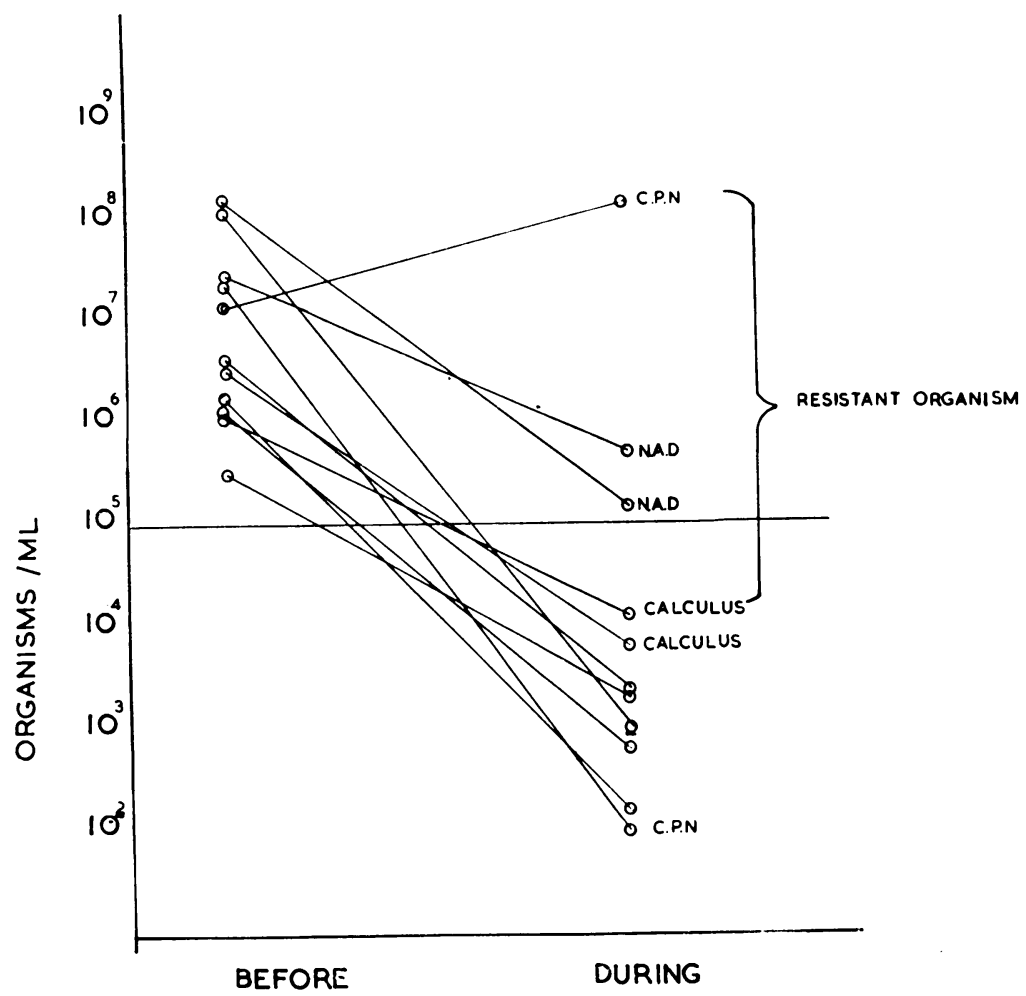

FIG. 1--Urinary bacterial coung in eleven patients with bacteriuria before and after one month of treatmen尺 with ampicillin $500 \mathrm{mg} \subseteq$ thrice daily.

Relevant findings on thes intravenous pyelogram aroo given in six cases. C.P.N등 =Chronic pyelonephritis $\overline{\overline{5}}$. Two of the three patientsin whom bacteriuria per $\frac{\mathbb{D}}{2}$ sisted in spite of treatmento had no demonstrable ab-s normality on the intraven $\overrightarrow{0}$ ous pyelogram. The organ $=$ ism in these three and in one patient with aO bacterial count of 15,0000 organisms per $\mathrm{ml}$. and an underlying renal calculus were resistant to ampit cillin at the time of theis second urine examination

AMPICILLIN 500 mg., t.d.s.

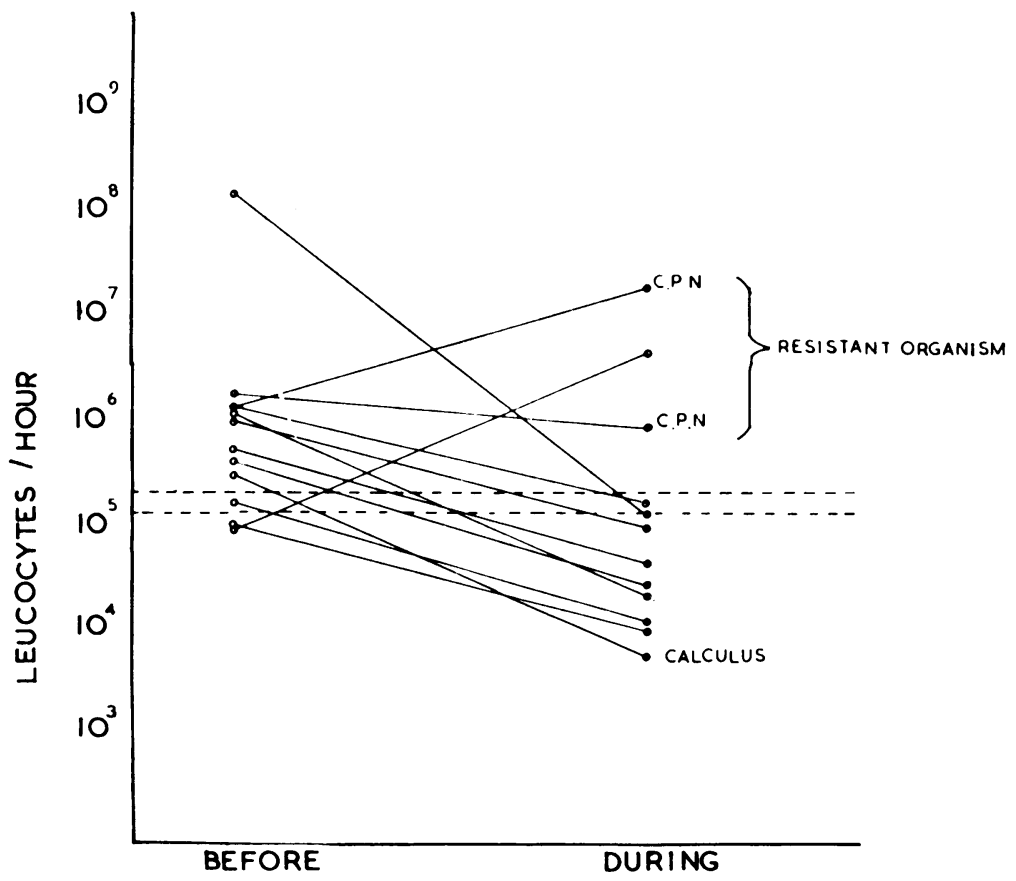

AMPICILLIN 500 mg., t.d.s. 


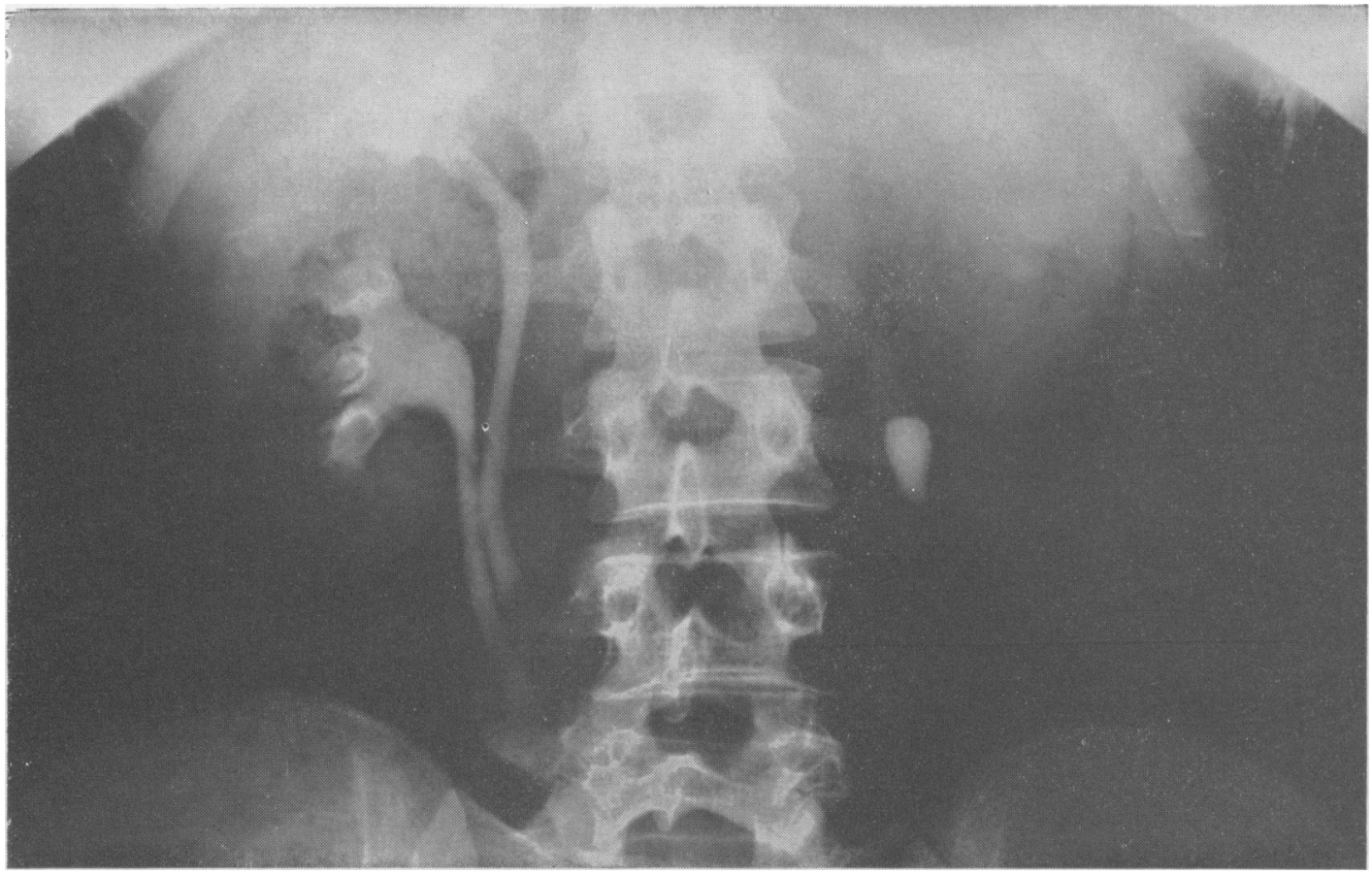

FIG. 3.-An intravenous pyelogram done in the post-partum period in a patient who presented with asymptomatic bacteriuria and in whom a high leucocyte excretion rate persisted for the remainder of pregnancy. A large left uretic calculus was present and there was very poor function and hydronephrosis on the left side. After removal of the calculus the function of the left kidney on an intravenous pyelogram was very much improved.

TABLE II

Radiological Lesions

IVP in 134 of 200 cases

\begin{tabular}{|c|c|c|}
\hline & No. & $\%$ \\
\hline Normal & 67 & 50 \\
\hline $\begin{array}{l}\text { Chronic pyelonephritis } \\
\text { Calyceal abnormalities including }\end{array}$ & & 9.7 \\
\hline $\begin{array}{l}\text { papillary necrosis } \\
\text { Localised scar probably chronic }\end{array}$ & 11 & 8.2 \\
\hline $\begin{array}{l}\text { pyelonephritis ( } 5 \text { also with } \\
>2 \mathrm{~cm} \text {. difference in length) }\end{array}$ & 11 & 75 \\
\hline Renal calculi & 10 & 7.5 \\
\hline $\begin{array}{l}\text { Duplex system } \\
\text { (3 with localised chronic } \\
\text { pyelonephritis) }\end{array}$ & 6 & 4.5 \\
\hline $\begin{array}{l}\text { (marked hydronephrosis } \\
\text { tuberculosis } \\
>2 \mathrm{~cm} \text {. difference in length) }\end{array}$ & 16 & 11.9 \\
\hline TOTAL & 134 & 100 \\
\hline
\end{tabular}

patients were unable to take ampicillin because of vomiting and one failed to show any clinical or bacteriological response and the organism apparently became resistant to this drug.
Two of the 21 patients who showed an initial response relapsed a week after treatment had been stopped. One of these had a ureteric calculus, but the intravenous pyelogram was normal in the other.

Six patients did not attend for post-partum follow-up, but of the remaining 18 patients five developed urinary tract infection in the early post-partum period and in three other patients asymptomatic infection was present six months after delivery. Only one of these three showed a radiological abnormality.

\section{Treatment of Post-partum Pyelonephritis}

Eleven patients who developed pyelonephritis in the first three months after delivery were treated with $500 \mathrm{mg}$. ampicillin four times a day for two weeks.

Nine of these 11 patients had radiological evidence of an underlying chronic renal lesion. 
TABLE III

Ampicillin in Pyelonephritis of Pregnancy

Total cases (7 with I.V.P. abnormality)

Unable to take ampicillin (vomiting)

Initial response, bacterial count normal 3 days after ampicillin stopped

Failed to respond. Resistant organism appeared

Relapse within a week

Follow-up post-partum

Urinary infection in early post-partum period

Urinary infection 6 months postpartum

21

The results are given in Table IV. In spite of an apparent initial clinical response to treatment in ten of the 11 patients, four showed persistent infection while still receiving ampicillin. In two patients the organism appeared to have become resistant to ampicillin and in the other two a different infection resistant to ampicillin had appeared. In the patient who failed to show any clinical response, the organism had apparently become resistant to ampicillin. In all these patients infection recurred within the next six months.

\section{Discussion}

In the patients in whom asymptomatic bacteriuria in pregnancy was treated with ampicillin, $54 \%$ had a radiological abnormality demonstrated in the intravenous pyelogram. Garrod, Shooter and Curwen (1954) showed that only $60 \%$ of patients with a demonstrable urinary tract abnormality will develop a sterile urine following treatment. We obtained a satisfactory response in $72 \%$ of this small group of bacteriuric women. However the second bacterial count was done while the patient was receiving ampicillin and the findings must be interpreted with caution as the ampicillin in the urine could have been bacteriostatic in some cases.

Patients who developed a frank attack of pyelonephritis of pregnancy had a much lower incidence $(29 \%)$ of demonstrable renal abnormalities and $87 \%$ of these were bacteriologically free of infection three days after stopping treatment.

The group of patients in whom we studied the effect of ampicillin on post-partum pyelonephritis had a very high $(81 \%)$ incidence of demonstrable radiological abnormalities and as might be expected only $54 \%$ of these
TABLE IV

Ampicillin in Post-Partum Pyelonephritis

Total cases (9 with I.V.P. abnormality)

Initial response, bacterial count normal 3 days after treatment stopped

Clinical response but infection reappeared while patient on treatment

Failed to respond clinically or bacteriologically

Recurrence during next 6 months

No.

$\%$

11

$54.5 \frac{\bar{m}}{\mathrm{~m}}$

36.3 ஸ

patients had a bacteriological response treatment.

Thus our experience with ampicillin it bacteriuria and pyelonephritis of pregnanc $\$$ suggests that it is an effective drug whic can be given with safety in pregnancy. Side effects, particularly vomiting, were common.

\section{Summary}

Ampicillin has proved satisfactory for the treatment of bacteriuria and pyelonephritisoip pregnancy. Vomiting was a troublesome sidd effect.

I am grateful to the Obstetricians at the Que्हen Victoria Hospital for permitting me to study theif patients, to my able assistant Dr. M. Bullen anf to Dr. J. Mills for help with the clinical side of this study.

Mrs. U. Fussell, Research Bacteriologist and Mis̊ Fay Goon did most of the bacteriological work an\& Dr. Elsie Abrahams, Miss Heather Maclay and Miss Nedra Huston gave us helpful advice on the bacteriological aspects. Miss Merrill Wilson pre pared the figures and helped in many other ways? Mr. Berkshire of the Photographic Department a the Queen Victoria Hospital was responsible for the photography.

The Committee of Management of the Queen Victoria Hospital made bacteriological equipment and materials available to us.

Felton Bequest Committee covered most of the expenses with a generous research grant and Bee-3 chams Research Laboratories, England supplied the ampicillin (Penbritin) used in this study.

\section{REFERENCES}

Garrod, L. P., Shooter, R. A., and Curwen, M. Po 1954): Brit. med. J., ii, 1003.

KarTz, A. L., and HodDER, E. W. (1961): New EngRु J. Med., 265, 667.

KaSS, E. H. (1962): Ann. intern. Med., 105, 194.

KASS, E. H. (1962): Ann. intern. Med., 56, 46.

Turk, M., Goffe, B. S., and Petersdorf, R. Q (1962): New Engl. J. Med., 266, 857.

TURNER, G. C. (1961): Lancet, ii, 1062. 